\title{
ATTRACTIVENESS, TRUSTWORTHINESS AND PURCHASE INTENTION IN SOCIAL MEDIA INSTAGRAM: THE MODERATING ROLE OF THE NUMBER OF FOLLOWERS
}

\author{
Dewi Tamara, Rudy Rafly, Arimbi Mersi \\ Business School Master Program, Bina Nusantara University, Jakarta, Indonesia \\ Email: dtamara@binus.edu, rudy.rafly@binus.ac.id, arimbimersi97@gmail.com
}

\begin{abstract}
This study examines the influence of influencers' credibility on purchase intention on Instagram. The framework in this study includes attractiveness and trustworthiness as an indicator of influencer credibility and independent variables, number of followers as moderator, and purchase intention as dependent variable. Respondents in this study were 200 Instagram users in Indonesia who had done via Instagram. The results show that attractiveness and trust have a positive effect on purchase intention. And, the number of followers moderates the relationship between attractiveness to purchase intention and trustworthiness to purchase intention. In addition, the results of this study also prove that the number of followers has a direct influence on purchase intention. This study contributes to the product endorsement literature, how an influencer can increase the purchase intention of a consumer on Instagram social media.
\end{abstract}

Keywords: social media influencer; source credibility; number of follower; purchase intention; instagram

\section{Introduction}

In this day and age, the Internet is a media that is very popular with the people. The internet is the right place for people to receive information and develop their skills in social media. Based on (Hootsuite, 2020) data, in 2020 the total population in Indonesia is 272.1 inhabitants. Where the number of internet users reaches 175.4 million users. The number of active social media users has reached 160 million people.

Therefore, social media is growing rapidly along with the very fast growth of the internet. Social media changes the old one-way communication method to communicate and influence each other (Ki, Cuevas, Chong, \& Lim, 2020). Everyone can put forward an opinion that others can see. Social media can be used as a place to find sources of information and find useful content if it is used actively and regularly (Jiménez-Castillo \& Sánchez-Fernández, 2019).

One of the most well-known social media is Instagram. On this platform, there are many types of products that are marketed or promoted. The promotion is carried out by social media influencers, where social media influencers have experienced a wave of popularity in the last few years to carry out product promotions. This is inseparable from how big the social media influencer's capacity is in reaching the number of

$\begin{array}{ll}\text { How to cite: } & \text { Tamara, D., Rafly, R., \& Mersi, A. (2021) Attractiveness, Trustworthiness and Purchase Intention in } \\ & \text { Social Media Instagram: The Moderating Role of The Number of Followers, Syntax Idea, 3(8), } \\ & \text { https://doi.org/10.36418/syntax-idea.v3i8.1453 } \\ \text { E-ISSN: } & 2684-883 \mathrm{X} \\ \text { Published by: } & \text { Ridwan Institute }\end{array}$


followers. Therefore, it is important to know the credibility of a social media influencer. To assess the credibility of a social media influencer, there are various indicators, including attractiveness and trustworthiness (Weismueller, Harrigan, Wang, \& Soutar, 2020). In addition, recently there has been a stimulus from the public that the number of followers of a social media influencer will affect the credibility and interest of consumers in buying products promoted by these social media influencers (Schouten, Janssen, \& Verspaget, 2020).

The purpose of this study was to examine the moderating effect of the number of followers by analyzing the relationship between attractiveness and trustworthiness on purchase intention on Instagram. Influencers can convey the message that a brand wants to convey to the intended target audience, namely its followers. In addition, influencers can be considered valuable and trustworthy sources for their followers. According to (Jiménez-Castillo \& Sánchez-Fernández, 2019), they believe that influencers have the power to persuade consumers to buy products from a brand being promoted.

Along with the growth of social media, especially Instagram, has become one of the communication instruments that receive special attention because it can introduce products to consumers effectively. Instagram can not only be used to share photos but can also be used as a medium for promotion.

One of the most commonly used promotions on Instagram is paid promotion (endorsement). One of the endorsement service providers comes from hundreds or even thousands of Instagram followers, while endorsement service users are business owners or certain brands who want to promote their products (Bentz \& Veltri, 2020).

Along with the rise of social media influencers on Instagram social media, various studies have been conducted on social media influencers and purchase intention. However, there is no research that proves a relationship between followership and endorsement with social media influencers. Several studies that have been conducted by (Dwidienawati, Tjahjana, Abdinagoro, \& Gandasari, 2020), (Lim, Radzol, Cheah, \& Wong, 2017), (Osei-Frimpong, Donkor, \& Owusu-Frimpong, 2019), (Soesilo, Komajaya, \& Prasetyaningtyas, 2020), (Trivedi \& Sama, 2020), (De Veirman, Cauberghe, \& Hudders, 2017), (Weismueller et al., 2020), and (Tong \& Su, 2018) examined the influence of social media and trust on purchase intention. There are still very few studies that use the number of followers variable. (Weismueller et al., 2020) conducted a study on the relationship between advertising disclosure, source credibility, purchase intention, and number of followers as control variables carried out on respondents to Instagram users in Germany. Meanwhile, in this study the number of followers variable moderates the relationship between the credibility of social media influencers (attractiveness \& trustworthiness) and purchase intention with respondents who are domiciled in Indonesia to prove whether the number of followers will strengthen or weaken the influence of the social media influencer credibility variable on purchase intention. 


\section{Research Methods}

This chapter discusses the types of research, objects, subjects and locations of research, data sources, research variables and variable measurements, data collection methods, sampling methods, and data analysis techniques.

1. Types of Research

This research belongs to the type of quantitative research to examine phenomena that can be expressed in terms of the quantity obtained from the measurement of research variables using a Likert scale which is then analyzed using one type of statistical technique.

This research uses descriptive research. According to (Sekaran \& Bougie, 2019), descriptive research is often designed to collect data that describes the characteristics of objects (such as people, product organizations, or brands), events or situations. Descriptive research can also be used to find the causes of variables (Kothari, 2004). directly by researchers, while secondary data is indirect data collected by researchers.

The data source used in this study is the primary data source. The primary data source of this study was obtained from a survey through a questionnaire. This questionnaire will be created via Google Forms and distributed online to respondents by sharing an accessible link to fill out the questionnaire.

2. Research object, subject, and location

The research objects used are attractiveness, trustworthiness, number of followers, and purchase intention. The subjects in this study were men and women in Indonesia who used social media Instagram as a forum for expressing social activities for at least the last 3 months and had purchased products at least once via Instagram.

3. Data Source

Data sources can be divided into primary data and secondary data. Primary data is the data that is collected.

4. Research variables and variable measurements

The independent variables in this study are attractiveness and trustworthiness. The dependent variable of this study is purchase intention. The moderator variable is number of followers.

Table 1

Research variables and variable measurements

\begin{tabular}{|c|c|c|c|c|c|}
\hline Variabel & Definition & Indicator & Instrument & Scale & Source \\
\hline \multirow{4}{*}{$\begin{array}{l}\text { Attractiv } \\
\text { eness }\end{array}$} & \multirow{4}{*}{$\begin{array}{l}\text { Influencers who } \\
\text { are attractive } \\
\text { are consistently } \\
\text { more preferred } \\
\text { and have a } \\
\text { positive impact } \\
\text { on the products } \\
\text { they advertise }\end{array}$} & Attractive & $\begin{array}{l}\text { I prefer influencers } \\
\text { with good looks }\end{array}$ & \multirow{4}{*}{$\begin{array}{c}\text { Likert } \\
5- \\
\text { point }\end{array}$} & \multirow{4}{*}{$\begin{array}{c}\text { (Najib et } \\
\text { al., } \\
\text { 2019) }\end{array}$} \\
\hline & & Classy & $\begin{array}{l}\text { I prefer influencers } \\
\text { with a classy style }\end{array}$ & & \\
\hline & & Beautiful & $\begin{array}{l}\text { I prefer influencers } \\
\text { with good faces }\end{array}$ & & \\
\hline & & Elegant & $\begin{array}{l}\text { I prefer influencers } \\
\text { with an elegant }\end{array}$ & & \\
\hline
\end{tabular}




\begin{tabular}{|c|c|c|c|c|c|}
\hline Variabel & Definition & Indicator & Instrument & Scale & Source \\
\hline & & & style & & \\
\hline & & Sexy & $\begin{array}{l}\text { I prefer influencers } \\
\text { with the ideal body } \\
\text { shape }\end{array}$ & & \\
\hline \multirow{5}{*}{$\begin{array}{l}\text { Trustwor } \\
\text { thiness }\end{array}$} & \multirow{5}{*}{$\begin{array}{l}\text { Trustworthiness } \\
\text { refers to the } \\
\text { honesty, } \\
\text { integrity and } \\
\text { trustworthiness } \\
\text { of the source }\end{array}$} & Dependable & $\begin{array}{l}\text { I prefer influencers } \\
\text { who can stick with } \\
\text { them }\end{array}$ & \multirow{5}{*}{$\begin{array}{l}\text { Likert } \\
5- \\
\text { point }\end{array}$} & \multirow{5}{*}{$\begin{array}{l}\text { (Najib et } \\
\text { al., } \\
\text { 2019) }\end{array}$} \\
\hline & & Honest & $\begin{array}{l}\text { I prefer honest } \\
\text { Influencers }\end{array}$ & & \\
\hline & & Reliable & $\begin{array}{l}\text { I prefer influencers } \\
\text { who are reliable }\end{array}$ & & \\
\hline & & Sincere & $\begin{array}{l}\text { I prefer sincere } \\
\text { influencers }\end{array}$ & & \\
\hline & & Trustworthy & $\begin{array}{l}\text { I prefer trusted } \\
\text { influencers }\end{array}$ & & \\
\hline \multirow{3}{*}{$\begin{array}{l}\text { Number } \\
\text { of } \\
\text { Follower } \\
\text { s }\end{array}$} & \multirow{3}{*}{$\begin{array}{c}\text { The number of } \\
\text { followers on } \\
\text { social } \\
\text { networking sites } \\
\text { is a measure of } \\
\text { online } \\
\text { popularity, } \\
\text { which can be a } \\
\text { predictor of the } \\
\text { credibility of } \\
\text { social media } \\
\text { users }\end{array}$} & & $\begin{array}{lr}\text { I prefer influencers } \\
\text { with a large } \\
\text { number } & \text { of } \\
\text { followers } & \\
\end{array}$ & \multirow{3}{*}{$\begin{array}{l}\text { Likert } \\
5- \\
\text { point }\end{array}$} & $\begin{array}{l}\text { (Weismu } \\
\text { eller et } \\
\text { al., } \\
\text { 2020) }\end{array}$ \\
\hline & & & $\begin{array}{lr}\text { I } & \text { choose } \\
\text { influencers } & \text { whose } \\
\text { followers } & \text { always } \\
\text { increase } & \\
\end{array}$ & & $\begin{array}{l}\text { (Rafly \& } \\
\text { Mersi, } \\
\text { 2021) }\end{array}$ \\
\hline & & & $\begin{array}{l}\text { Influencers with a } \\
\text { large number of } \\
\text { followers made me } \\
\text { aware of the } \\
\text { products being } \\
\text { promoted }\end{array}$ & & $\begin{array}{l}\text { (Agam, } \\
\text { 2017) }\end{array}$ \\
\hline \multirow{3}{*}{$\begin{array}{l}\text { Purchase } \\
\text { Intention }\end{array}$} & \multirow{3}{*}{$\begin{array}{c}\text { Intention to buy } \\
\text { is a conscious } \\
\text { plan an } \\
\text { individual } \\
\text { makes an } \\
\text { attempt to buy a } \\
\text { product }\end{array}$} & & $\begin{array}{l}\text { I can imagine } \\
\text { buying a product }\end{array}$ & \multirow{3}{*}{$\begin{array}{l}\text { Likert } \\
5- \\
\text { point }\end{array}$} & \multirow{3}{*}{$\begin{array}{l}\text { (Weismu } \\
\text { eller et } \\
\text { al., } \\
\text { 2020) }\end{array}$} \\
\hline & & & $\begin{array}{l}\text { I will consider } \\
\text { before buying a } \\
\text { product }\end{array}$ & & \\
\hline & & & $\begin{array}{l}\text { I am very } \\
\text { interested in buying } \\
\text { a product }\end{array}$ & & \\
\hline
\end{tabular}

5. Method of Collecting Data

The data collection method in this study is a survey method through a questionnaire. The questionnaire was created using Google Forms and distributed online to men and women in Indonesia who have used Instagram social media for at least 3 months and have purchased a product at least once via Instagram.

Furthermore, in the second part of the questionnaire respondents are asked to fill in questions regarding the respondent's profile such as age, gender, occupation 
and domicile. The third part of the questionnaire contains questions related to all the variables studied as in table 1 .

6. Sampling Method

Data collection using sampling techniques. In this study, the target population is men and women living in Indonesia. The sample frame in this study is men and women who live in Indonesia, have used Instagram social media for at least the last 3 months and have purchased products at least once via Instagram. In this study the authors chose a non-probability sampling technique in which not all individuals can participate as respondents. This type of judgment sampling method was chosen because it has certain criteria with the aim of obtaining the type of information needed from a very specific group of people who have the facts needed, so that they can provide the information they want to target. This is in accordance with the selected sample criteria, namely men and women who live in Indonesia, have used Instagram social media for at least the last 3 months and have purchased products at least once via Instagram. In this study, the authors used Structural Equation Modeling (SEM) as a data analysis technique. (Shiau, Sarstedt, \& Hair, 2019) stated that PLS-SEM has a general rule in determining sample size called the 10-times rule, where the minimum number of samples is ten times or more than the maximum number of structural paths that point to latent variables.

In this study, there are twelve paths that lead to variables. Thus, the determination of the minimum number of samples was 40 respondents. However, to strengthen the research results, the researcher will use 200 samples so that it has exceeded the sample requirements for PLS-SEM Fifth, data collection. The researcher will collect data by distributing questionnaires. The questionnaire is digital and uses the Google Form platform. The researcher will select data from the questionnaire that has been obtained. Data selection is carried out to select data that is suitable for processing. The data is deemed fit for processing if the data is completely filled in and answered in earnest.

7. Data Analysis Technique

This study uses a Variance Based Partial Least Squares (PLS-SEM) model. (Shiau et al., 2019) states that evaluating the PLS-SEM results involves two stages in the "Rules of Thumb for Model Evaluation" table, first testing measurement models, with varying analyzes depending on whether the model includes reflective, formative, or both. consisting of composite reliability must be greater than 0.70 to measure the consistency reliability interval ( 0.60 to 0.70 in exploratory studies is acceptable). Loadings indicator value must be higher than 0.70 to measure indicator reliability, which indicates that the construction can explain more than $50 \%$ of the variance indicator. The acceptable Average Variance Extracted (AVE) is higher than 0.50 to measure convergent validity. To test for discriminant validity, the AVE of each latent construct must be higher than the highest-square correlation of the other constructs in the framework model. Multicollinearity testing is important for regression models, to determine whether there is intercorrelation or collinearity 
between two or more independent variables in multiple regression models. In multiple regression it is expected that there will be no collinearity with Variance Inflation Factor (VIF) as an indicator that must have a value of less than 5.

Second, the structural model (structural models) to determine whether the structural relationship is significant, significant, and to test the hypothesis, namely $\mathrm{R} 2$ in endogenous constructs has a range from 0 to 1 , a higher level indicates a higher level of prediction accuracy. R2 values of $0.75,0.50$, and 0.25 can be considered as strong, moderate, and weak. Assess the significance of the path coefficient using bootstrapping with a minimum sample size of 5000. Path coefficient values are standardized over the range from 1 to +1 , with coefficients close to +1 representing a strong positive relationship, while closer to 1 indicating a strong negative relationship. Furthermore, the critical t-values on the two-tailed test were 1.65 ( ignificance level $=10$ percent), 1.96 (significance level $=5 \%$ ), and 2.58 ( ignificance level $=1$ percent). In this study, the significance level used was $5 \%$, so the critical t-value as the reference was 1.96.

\section{Results and Discussions}

1. Respondent Characteristics

Table 1

Respondent Characteristics

\begin{tabular}{cccc}
\hline \multirow{2}{*}{ Age } & & Amount & \% \\
\cline { 2 - 4 } & $0-30$ & 90 & $45 \%$ \\
\cline { 2 - 4 } & $31-60$ & 93 & $46.5 \%$ \\
\hline \multirow{2}{*}{ Gender } & $61-75$ & 17 & $8.5 \%$ \\
& Male & 72 & $36 \%$ \\
\cline { 2 - 4 } Domicile & Jemale & 128 & $64 \%$ \\
\hline
\end{tabular}

$45 \%$ of the total respondents were $0-30$ years old, $46.5 \%$ were $31-60$ years old, and $8.5 \%$ were $61-75$ years old. Of all respondents, $36 \%$ were male and $64 \%$ female. The majority of respondents' domicile is Jabodetabek with a percentage of $69.5 \%$ of the total respondents (see Table 1)

2. Descriptive statistics

Tabel 2

Descriptive statistics

\begin{tabular}{ll}
\hline \multicolumn{1}{c}{ Indicator } & Mean \\
\hline TR 2: I prefer honest influencers & 4.565 \\
\hline $\begin{array}{l}\text { A 5: I prefer influencers with the ideal } \\
\text { body shape }\end{array}$ & 3.565 \\
\hline
\end{tabular}

Based on descriptive statistics, for all questions or variable indicators, from a Likert scale of 1 to 5 , it was found that the average value was more than 3 . 
Trustworthiness had the highest average value of 4,565. The lowest is attractiveness with an average of 3,565 (see Table 2).

3. Validity and Reliability Tests

Tabel 3

Validity and Reliability Tests

\begin{tabular}{|c|c|c|c|c|c|c|c|}
\hline $\begin{array}{c}\text { Latent } \\
\text { Variabel }\end{array}$ & Indicator & $\begin{array}{c}\text { Loading } \\
\text { Factor } \\
(>0.5)\end{array}$ & T-Stat & AVE & Remark & $\mathbf{C R}$ & $\begin{array}{c}\text { Latent } \\
\text { Variabel }\end{array}$ \\
\hline \multicolumn{8}{|c|}{ Independent Variables } \\
\hline \multirow{5}{*}{ Attractiveness } & A1 & 0.836 & 34.105 & \multirow{5}{*}{0.652} & Valid & \multirow{5}{*}{0.903} & Valid \\
\hline & $\mathrm{A} 2$ & 0.814 & 18.927 & & Valid & & Valid \\
\hline & A3 & 0.871 & 39.827 & & Valid & & Valid \\
\hline & A4 & 0.770 & 14.416 & & Valid & & Valid \\
\hline & A5 & 0.740 & 13.951 & & Valid & & Valid \\
\hline \multirow{5}{*}{ Trustworthiness } & TR1 & 0.847 & 31.113 & \multirow{5}{*}{0.778} & Valid & \multirow{5}{*}{0.946} & Valid \\
\hline & TR2 & 0.879 & 23.269 & & Valid & & Valid \\
\hline & TR3 & 0.888 & 31.915 & & Valid & & Valid \\
\hline & TR4 & 0.909 & 38.551 & & Valid & & Valid \\
\hline & TR5 & 0.889 & 36.774 & & Valid & & Valid \\
\hline \multicolumn{8}{|c|}{ Moderating Variable } \\
\hline \multirow{3}{*}{$\begin{array}{l}\text { Number of } \\
\text { Followers }\end{array}$} & NOF 1 & 0.865 & 28.117 & \multirow{3}{*}{0.784} & Valid & \multirow{3}{*}{0.916} & Valid \\
\hline & NOF 2 & 0.889 & 41.762 & & Valid & & Valid \\
\hline & NOF 3 & 0.902 & 58.208 & & Valid & & Valid \\
\hline \multicolumn{8}{|c|}{ Dependent Variable } \\
\hline \multirow{3}{*}{$\begin{array}{l}\text { Purchase } \\
\text { Intention }\end{array}$} & PI 1 & 0.846 & 32.804 & \multirow{3}{*}{0.623} & Valid & \multirow{3}{*}{0.832} & Valid \\
\hline & PI 2 & 0.763 & 9.666 & & Valid & & Valid \\
\hline & PI 3 & 0.755 & 13.618 & & Valid & & Valid \\
\hline
\end{tabular}

Tabel 4

Fornell-Larcker Criteria Table

\begin{tabular}{lcccccc}
\hline & Attractiveness & $\begin{array}{c}\text { Moderating } \\
\text { Effect 1 }\end{array}$ & $\begin{array}{c}\text { Moderating } \\
\text { Effect 2 }\end{array}$ & $\begin{array}{c}\text { Number } \\
\text { of } \\
\text { Followers }\end{array}$ & Purchase & Attractiveness \\
\hline Attractive- & 0.807 & & & & & \\
\hline Moderating Effect 1 & -0.297 & 1.000 & & & & \\
\hline Moderating Effect 2 & -0.212 & 0.568 & 1.000 & & & \\
\hline $\begin{array}{l}\text { Number of } \\
\text { Followers }\end{array}$ & 0.562 & -0.157 & -0.123 & 0.886 & & \\
\hline Purchase Intention & 0.507 & -0.123 & -0.402 & 0.496 & 0.790 & \\
\hline $\begin{array}{l}\text { Trustworthi- } \\
\text { ness }\end{array}$ & 0.393 & -0.229 & -0.545 & 0.303 & 0.606 & 0.882 \\
\hline
\end{tabular}

We do data processing using structural equation modeling with partial least square (PLS) as an alternative based on variants. In the structural equation modeling, PLS uses two stages of evaluation. The first stage is the outer model, which is to determine the validity and reliability of each research indicator. The second stage is the inner model which aims to determine the relationship between latent variables. 
All indicators of all related variables show a loading factor> 0.5. Composite reliability (CR) for all variables is also>0.7. AVE scores for all variables were also> 0.5 . Therefore, it can be concluded that the measurement is reliable and valid (see Table 4.3). The discriminant validity test using Fornell-Larcker criteria shows that the root square AVE of all variables is the highest among variables, compared to other variables. This shows that all tested variables have good discriminant validity (see Table 3).

4. Structural model analysis

Tabel 5

R square

\begin{tabular}{ccc}
\hline & R Square & R Square Adjusted \\
\hline Purchase Intention & 0.532 & 0.520 \\
\hline
\end{tabular}

In this study, the structural model was tested using the R-square test. The rsquare of this study is 0.532 . This shows that the attractiveness \& trustworthiness variable moderated by the number of followers has an effect of $53.2 \%$ on purchase intention, while the remaining $46.8 \%$ is influenced by other variables. (See 5).

\section{Conclusion}

The state of the number of followers is an important point for an influencer to be able to have a good influence in making the intention to buy a product on social media, namely Instagram. The number of followers is dominated by some information and has an impact on consumers to believe and be able to find every concrete thing, starting from consumers who think that buying a product that is promoted can create an understanding that influencers can be more attractive and trustworthy. No previous research has examined the impact of the number of followers but as a result of research that can be updated. This study shows the success of a moderating effect of number of followers on trustworthiness and consumer attractiveness towards purchase intention of a product. 


\section{BIBLIOGRAFI}

Bentz, Tamany Vinson, \& Veltri, Carolina. (2020). The Indirect Regulation of Influencer Advertising. Food \& Drug LJ, 75, 185.Google Scholar

De Veirman, Marijke, Cauberghe, Veroline, \& Hudders, Liselot. (2017). Marketing through Instagram influencers: the impact of number of followers and product divergence on brand attitude. International Journal of Advertising, 36(5), 798-828. Google Scholar

Dwidienawati, Diena, Tjahjana, David, Abdinagoro, Sri Bramantoro, \& Gandasari, Dyah. (2020). Customer review or influencer endorsement: which one influences purchase intention more? Heliyon, 6(11), e05543. Google Scholar

Hootsuite, We Are Social. (2020). Digital 2020. Indonesia. Hootsuite, United State.

Jiménez-Castillo, David, \& Sánchez-Fernández, Raquel. (2019). The role of digital influencers in brand recommendation: Examining their impact on engagement, expected value and purchase intention. International Journal of Information Management, 49, 366-376. Google Scholar

Ki, Chung Wha Chloe, Cuevas, Leslie M., Chong, Sze Man, \& Lim, Heejin. (2020). Influencer marketing: Social media influencers as human brands attaching to followers and yielding positive marketing results by fulfilling needs. Journal of Retailing and Consumer Services, 55, 102133. Google Scholar

Kothari, Chakravanti Rajagopalachari. (2004). Research methodology: Methods and techniques. New Age International. Google Scholar

Lim, Xin Jean, Radzol, A. M., Cheah, J., \& Wong, Mun W. (2017). The impact of social media influencers on purchase intention and the mediation effect of customer attitude. Asian Journal of Business Research, 7(2), 19-36. Google Scholar

Osei-Frimpong, Kofi, Donkor, Georgina, \& Owusu-Frimpong, Nana. (2019). The impact of celebrity endorsement on consumer purchase intention: An emerging market perspective. Journal of Marketing Theory and Practice, 27(1), 103-121. Google Scholar

Schouten, Alexander P., Janssen, Loes, \& Verspaget, Maegan. (2020). Celebrity vs. Influencer endorsements in advertising: the role of identification, credibility, and Product-Endorser fit. International Journal of Advertising, 39(2), 258-281. Google Scholar

Sekaran, Uma, \& Bougie, Roger. (2019). Research methods for business: A skill building approach. john wiley \& sons. Google Scholar

Shiau, Wen Lung, Sarstedt, Marko, \& Hair, Joseph F. (2019). Internet research using 
partial least squares structural equation modeling (PLS-SEM). Internet Research. Google Scholar

Soesilo, Theresia, Komajaya, Eka Putera, \& Prasetyaningtyas, Sekar Wulan. (2020). The Impact Of Attitude Towards Influencer In Social Media Influencer On Consumers' Purchase Intention: An Examination Across Gender. Solid State Technology, 63(4), 1258-1269. Google Scholar

Tong, Xiao, \& Su, Jin. (2018). Exploring young consumers' trust and purchase intention of organic cotton apparel. Journal of Consumer Marketing. Google Scholar

Trivedi, Jay, \& Sama, Ramzan. (2020). The effect of influencer marketing on consumers' brand admiration and online purchase intentions: An emerging market perspective. Journal of Internet Commerce, 19(1), 103-124. Google Scholar

Weismueller, Jason, Harrigan, Paul, Wang, Shasha, \& Soutar, Geoffrey N. (2020). Influencer endorsements: How advertising disclosure and source credibility affect consumer purchase intention on social media. Australasian Marketing Journal, 28(4), 160-170. Google Scholar

\section{Copyright holder:}

Dewi Tamara, Rudy Rafly, Arimbi Mersi (2021)

\section{First publication right:}

Syntax Idea

\section{This article is licensed under:}

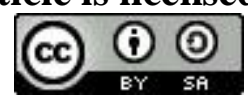

